\title{
Особливості державного регулювання міграційних процесів у Дніпропетровській області
}

\author{
К. М. Тарасенко \\ Університет митної справи та фінансів, Дніпро, Україна
}

\section{УДК 331.314.556}

doi: $10.15421 / 15201729$

Розглянуто основні причини міграції населення на прикладі Дніпропетровського регіону, як внутрішньої, так і зовнішньої. Виявлено чинники, які стимулюють трудову міграцію працездатного населення в цілому. Встановлено тенденцію до збільшення рівня смертності і помірного зростання рівня народжуваності. Розглянуто проблеми міграційних процесів, спричинені економічною кризою, безробіттям, низьким рівнем життя населення та політичною нестабільністю. Визначено, що кардинальним стимулом є різниця в оплаті праці, адже середньомісячний заробіток трудового мігранта приблизно 1000 дол. США, а середня заробітна плата дніпропетровця не перевищує 150 дол. США. 3'ясовано, що одним із факторів, який впливає на процеси сучасної міграції Дніпропетровщини, $є$ нестабільна ситуація, яка склалась на сході України та призвела до збільшення переміщених осіб, які значно підвищили кількість населення області. Проаналізовано сучасний стан міграційних потоків Дніпропетровської області, виявлено проблеми та запропоновано шляхи їх вирішення.

Ключові слова: міграція; міграційний потік; трудова міграція; міграційне сальдо; демографічна ситуація; ринок праці; безробіття

\section{The features of state regulation of migration processes in Dnipropetrovsk region}

\section{K. M. Tarasenko \\ University of customs and finance, Dnipro, Ukraine}

Dnipropetrovsk region - one of the most powerfull region in the economic aspect. A catual issue to the region is the study of the causes of migration, the definition of positive migration factors and the development of conditions for its expansion (the arrival of foreign students, highly skilled specialists, etc.) and the development of measures to prevent negative migration processes. This article discusses the main causes of migration, on an example Dnipropetrovsk region, both internal and external.

In the Dnipropetrovsk region, first of all, there is an outflow of the population as a temporary manifestation of the economic downturn. The main factor that stimulates the labormigration of the employee population is the difference in salary. The cardinal stimulus is the level of salary, because the average monthly earnings of a migrant worker are about $\$ 1,000$, while the average salary of Dnipropetrovs' $k$ does not exceed $\$ 150$. The problems of migration processes are caused by the economic crisis, unemployment, low living standards and political instability.

Today, for the migration processes in Dnipropetrovsk region, and Ukraine in general, the tendency towards intellectualization of the emigration. First and foremost, this tendency has caused the financial and economic problems of recent years, which resulted in the economic crisis. Indeed, under its conditions, a significant proportion of highly skilled professionals does not get the opportunity to properly apply their knowledge. As a result, the percentage of labor migrants from Ukraine employed in jobs requiring high qualifications - in medicine, science, high technology, and the financial sector - is growing. Moreover, one of the factors influencing the processes of modern migration of the Dnipropetrovsk region is the unstable situation in the East and has led to an increase in displaced persons, which significantly increased the population of the region.

Consequently, the main means of regulating the territorial movement of the population is to conduct

Цитування даної статті: Тарасенко К. М. Особливості державного регулювання міграційних процесів у Дніпропетровській області / К. М. Тарасенко // Аспекти публічного управління. - 2017. - Т.5. - №10. C. 5-12.

Citation of this article: Tarasenko, K.M. (2017). Osoblyvosti derzhavnoho rehuliuvannia mihratsiinykh protsesiv u Dnipropetrovskii oblasti [Features of state regulation of migration processes in the Dnipropetrovsk region] Public administration aspects, 5(10), 5-12.

Received: 21.09 .2017

Accepted: 10.10.2017 
a well-balanced migration policy and to strengthen the role of migration processes in socio-political and economic life. For example: expand the range of educational services; to increase the attractiveness of the region in view of the prospects of labor market proposals, adequate remuneration for work or favorable conditions for the conduct of its own business; create safe and comfortable living conditions; to improve the living conditions of the population for the influx of the population with experience, qualification or with the intention and financial capacity to start a business. That is, it is necessary to ensure the most efficient use of available labor potential by creating new jobs through the growth of investment in fixed assets and innovative development.

Keywords: migration; migration flow; labor migration; migration balance; demographics; labor market; unemployment

\title{
Особенности государственного регулирования миграционных процессов в Днепропетровской области
}

\author{
Е. Н. Тарасенко \\ Университет таможенного дела и финансов, Днепр, Украина
}

Рассмотрены основные причины миграции населения на примере Днепропетровского региона, как внутренней, так и внешней. Выявлены факторы, которые стимулируют трудовую миграцию трудоспособного населения в целом. Установлена тенденция к увеличению уровня смертности и умеренного роста уровня рождаемости. Рассмотрены проблемы миграционных процессов, вызванные экономическим кризисом, безработицей, низким уровнем жизни населения и политической нестабильностью. Определено, что кардинальным стимулом является разница в оплате труда, ведь среднемесячный заработок трудового мигранта примерно 1000 дол. США, а средняя заработная плата днепропетровца не превышает 150 дол. США. Установлено, что одним из факторов, который влияет на процессы современной миграции Днепропетровщины, является нестабильная ситуация, которая сложилась на востоке Украины и привела к увеличению перемещенных лиц, которые значительно повысили численность населения области. Проанализировано современное состояние миграционных потоков Днепропетровской области, выявлены проблемы и предложены пути их решения.

Ключевые слова: миграция; миграционный поток; трудовая миграция; миграционное сальдо; демографическая ситуация; рынок труда; безработица

Постановка проблеми. Своєрідною особливістю існування міграційних процесів у Дніпропетровській області є тенденція до збільшення обсягів внутрішніх та міждержавних міграційних переміщень населення. Сьогодні актуальною для Дніпропетровської області є проблема дослідження причин міграції, визначення факторів позитивної міграції та розвиток умов для іiі розширення (приїзд іноземних студентів на навчання, висококваліфікованих спеціалістів тощо), розробка заходів запобігання негативним міграційним процесам. Основним засобом регулювання територіального руху населення $€$ проведення виваженої міграційної політики та посилення ролі міграційних процесів у суспільно-політичному та економічному житті.

Аналіз досліджень і публікацій. Питанням вивчення міграційних процесів присвячені роботи багатьох як вітчизняних, так і зарубіжних науковців, таких як: T. А. Драгунова, Е. М. Лібанова, О. А. Ма- линовська, С. І. Пирожков, I. М. Прибиткова, М. Д. Романюк, С. Б. Чехович, М. О. Шульга та ін. Однак залишається нерозкритим вивчення проблем соціального та економічного характеру управління міграційними процесами та шляхів їх удосконалення.

Мета дослідження. Мета статті полягає в аналізі державного регулювання сучасного стану міграційних процесів Дніпропетровської області.

Виклад основного матеріалу. Дніпропетровська область - один із найбільш заселених в Україні, найпотужніших в економічному аспекті регіон. Різноманітність і значущість природних ресурсів, сприятливі кліматичні умови, корисні копалини, родючі чорноземи, активне бізнессередовище, а відповідно й більші можливості для працевлаштування - суттєві переваги для обрання Дніпропетровської області як місця проживання. В області існує розгалужена мережа навчальних 
закладів різних рівнів акредитації, заводів, підприємств та фінансово-кредитних установ тощо. Демографічна ситуація області сформувалась під впливом різних факторів, насамперед це пов'язано з високим економічним розвитком території, що, у свою чергу, впливає на структуру населення та їі розміщення. Однак, незважаючи на вищевикладене, за останні роки демографічна ситуація Дніпропетровської області, спричинена об'єктивними соціальними факторами, залишається невтішною і характеризується стійкою тенденцією до збільшення рівня смертності і помірного зростання рівня народжуваності [3, с. 34] (табл. 1).

Таблиия 1. Демографічна ситуація м. Дніпро, 2006 - 2016 рр.

\begin{tabular}{|c|c|c|c|c|c|c|c|c|}
\hline Рік & $\begin{array}{c}\text { Населен- } \\
\text { ня, осіб }\end{array}$ & $\begin{array}{c}\text { Народжу- } \\
\text { ваність, } \\
\text { осіб }\end{array}$ & $\begin{array}{c}\text { Смерт- } \\
\text { ність, } \\
\text { осіб }\end{array}$ & $\begin{array}{c}\text { Природ- } \\
\text { ний } \\
\text { пиріст, } \\
\text { осіб }\end{array}$ & $\begin{array}{c}\text { Середня } \\
\text { тривалість } \\
\text { життя, } \\
\text { роки }\end{array}$ & $\begin{array}{c}\text { Загаль- } \\
\text { ний } \\
\text { орипльв, } \\
\text { осіб }\end{array}$ & $\begin{array}{c}\text { Загаль- } \\
\text { ний } \\
\text { вілив, } \\
\text { осіб }\end{array}$ & $\begin{array}{c}\text { Сальдо } \\
\text { міграції, } \\
\text { осіб }\end{array}$ \\
\hline 2006 & 1039497 & 9571 & 15578 & -6007 & 68,5 & 12773 & 14625 & -1852 \\
\hline 2007 & 1031638 & 9788 & 15667 & -5879 & 68,4 & 11881 & 15957 & -4076 \\
\hline 2008 & 1021683 & 10748 & 15289 & -4541 & 69,0 & 8108 & 15551 & -7443 \\
\hline 2009 & 1009699 & 10723 & 14063 & -3340 & 70,7 & 10671 & 13648 & -2977 \\
\hline 2010 & 1003382 & 10105 & 14235 & -4130 & 70,8 & 12308 & 14482 & -2174 \\
\hline 2011 & 997058 & 10325 & 14454 & -4129 & 70,2 & 12200 & 13736 & -1536 \\
\hline 2012 & 991314 & 10310 & 14366 & -4056 & 70,5 & 12200 & 13936 & -1736 \\
\hline 2013 & 985843 & 10242 & 14262 & -4020 & 70,7 & 15336 & 14202 & -1134 \\
\hline 2014 & 993094 & 10114 & 14176 & -4062 & 70,9 & 13197 & 14673 & -1476 \\
\hline 2015 & 991600 & 9841 & 14695 & -4854 & 70,1 & 11008 & 12075 & -1351 \\
\hline 2016 & 978943 & 9384 & 14533 & -5149 & 70,1 & 11437 & 13783 & -2346 \\
\hline
\end{tabular}

У Дніпропетровській області, перш за все, спостерігається чистий відплив населення як тимчасовий прояв економічного спаду. Основною проблемою є від'ємне сальдо міграції. Два типи міграції внутрішня (міжрегіональна - у межах України) i міждержавна - роблять внесок у загальне сальдо міграції. Очевидно, що сальдо внутрішньої міграції $є$ різницею між кількістю людей, що приїхали в Дніпропетровську область 3 інших регіонів України, і тими, які виїхали до інших регіонів.

Чисельність наявного населення Дніпропетровської області на 1 серпня 2017 р., за попередніми даними, становила 3 239,4 тис. жителів. Упродовж 2016 р. вона скоротилася на 24,5 тис. осіб. Основним чинником, який вплинув на зміни чисельності населення, було його природне скорочення.
У 2015 р. міграційними потоками в регіоні було охоплено 76 тис. осіб, що на 2 тис. осіб менше ніж у 2014 р. У 2014 р. переїхали до області на постійне місце проживання майже на $15 \%$ менше осіб, ніж у попередньому році, при цьому кількість вибулих також зменшилася на 16,1 \%. А валова міграція 2014 р. скоротилася порівняно з 2013 p. на 15,3 \%. Традиційно в загальній чисельності прибулих та вибулих осіб більша частина $(61,1 \%)$ - це міграція по населених пунктах області, кожен третій мігрував у межах України та лише 5,6 \% - міждержавні мігранти [7]. Дані щодо міграційних потоків наведені в табл. 2.

Дніпропетровська область розташована в центральній частині країни. Отже, іiі територія значно віддалена від зовнішніх кордонів держави. Незалежно від цього фактору за станом на кінець 2015 р. на об- 
Таблиця 2. Міграційний рух населення в межах регіону, 2016 - 2014 рр.

\begin{tabular}{|c|c|c|c|c|c|c|c|}
\hline \multicolumn{9}{|c|}{ Рік } \\
\hline $\begin{array}{c}\text { Кількість } \\
\text { прибулих }\end{array}$ & $\begin{array}{c}\text { Кількість } \\
\text { вибулих }\end{array}$ & $\begin{array}{c}\text { Мiграцій- } \\
\text { ний } \\
\text { приріст, } \\
\text { скорочен- } \\
\text { ня (-) }\end{array}$ & $\begin{array}{c}\text { Кількість } \\
\text { прибулих }\end{array}$ & $\begin{array}{l}\text { Кількість } \\
\text { вибулих }\end{array}$ & $\begin{array}{c}\text { Міграцій- } \\
\text { ний } \\
\text { приріст, } \\
\text { скорочен- } \\
\text { ня (-) }\end{array}$ & $\begin{array}{c}\text { Кількість } \\
\text { прибулих }\end{array}$ & $\begin{array}{c}\text { Кількість } \\
\text { вибулих }\end{array}$ \\
\hline 11437 & 13783 & 2346 & 37594 & 38945 & 1351 & 39232 & 38803 \\
\hline
\end{tabular}

ліку в Головному управлінні міграційної служби України в Дніпропетровській області перебувало 22252 іноземці. Із них перебували тимчасово 4204 осіб, у тому числі 2329 іноземних студентів, які навчаються в 15 вищих навчальних закладах, що мають ліцензії на їх прийом. Найбільша кількість іноземців для отримання освіти в Україні прибула з таких країн, як Сирія, Туніс, Індія, Ірак, Йорданія, Китай, Конго. Водночас слід зазначити, що 18048 іноземних громадян проживають на території області постійно. Найбільш популярними серед іноземців $є$ медичні, технічні та культурні навчальні заклади, а також такі, що мають мало аналогів у світі, наприклад Національний гірничий університет, де навчаються студенти навіть із Західної Європи. Серед затребуваних спеціальностей - геологи, геодезисти та авіабудівники. По-перше, здобувати вищу освіту в Україні відносно недорого порівняно 3 іншими країнами. Подруге, в Україні якісна академічна школа i рівень отриманих знань. По-третє, є гарантія того, що якщо ти приїхав учитися, то точно довчитися, адже в Західній Європі процедура набагато складніша і там диплом отримує далеко не кожен. По-четверте, прекрасна можливість переїхати жити в більш розвинену державу заходу, що насамперед цікавить студентів із бідніших держав. I це позитивний тренд, оскільки, з одного боку, це визнання якості української освіти, а 3 іншого - джерело надходження коштів. Отже, іноземці як мігранти не впливають негативно на м. Дніпро, адже більшість із них повертається додому, а ті, хто вирішив залишитися, займають робочі місця переважно в торгівлі.

Щодо внутрішньої міграції, то 3 інших регіонів країни та 3-за кордону прибу- ло 15,4 тис. мігрантів, а виїхало за іiі межі 15 тис. осіб. Значно збільшилася кількість прибулих у 2014 р. саме через переселенців зі сходу. Із загальної кількості переселенців відомо, що наразі на Дніпропетровщині проживає 46 тис. 592 родини. У тому числі серед працездатного населення: кількість чоловіків-переселенців становить 9 тис. 750 осіб, жінок - 20 тис. 388 осіб. Іншу частину становлять діти, підлітки та пенсіонери. Головним питанням для вимушених переселенців є житлове питання. Наступна проблема після його вирішення - працевлаштування [2].

Ще одним фактором, що впливає на процеси сучасної міграції в Дніпропетровській області, є нестабільна ситуація, яка склалася на сході. Ця ситуація призвела до збільшення тимчасово переміщених осіб, які потребують працевлаштування, облаштування житлових умов та соціальної допомоги. Певні кроки в цьому напрямі зробив Кабінет Міністрів України, який 1 жовтня 2014 р. прийняв Постанову № 505 «Про надання щомісячної адресної допомоги особам, які переміщуються з тимчасово окупованої території України та районів проведення антитерористичної операції, для покриття витрат на проживання, у тому числі на оплату житлово-комунальних послуг». Обсяг щомісячних виплат на сім'ю не може перевищувати 2400 грн. [8]. Проте існують певні обмеження для отримання цієї допомоги. Так, якщо працездатна особа не працює, не перебуває на обліку в центрі зайнятості й не буде вирішувати питання 3 особистого працевлаштування, через два місяці розмір виплати буде зменшено на $50 \%$, а в подальшому вона й узагалі буде скасована. Незалежно від того, якого числа людина звернеться до управління праці та 
соціального захисту населення, допомога буде призначена на 6 місяців. Таким чином, щонайменше на півроку переселенці будуть забезпечені коштами для проживання та оплати житлово-комунальних послуг. Допомога на оплату проживання та комунальних послуг для переселенців не виключає інших соціальних виплат - малозабезпеченим сім'ям, самотнім матерям тощо. Тобто кожен переселенець забезпечений особистою економічною безпекою.

Призначення та виплату грошової допомоги здійснюють органи соціального захисту населення за фактичним місцем проживання (перебування) за заявою уповноваженого представника сім'ї. Звідси виходить, що кожен місяць із місцевого бюджету виділяється грошова допомога для непрацездатних осіб (пенсіонери, інваліди, діти) в розмірі 884 грн на одну особу, а для працездатних осіб - 442 грн на одну особу. Не призначається грошова допомога в разі, коли сім'я має у володінні житлове приміщення, що перебуває в регіонах, інших, ніж тимчасово окупована територія України та зони АТО, два і більше транспортних засобів, що підлягають державній реєстрації та обліку в Державтоінспекції, на депозитному банківському рахунку кошти в розмірі, більшому ніж 10-кратний прожитковий мінімум для працездатних осіб (12 180 грн) [5]. Це свідчить про суттєві виплати з бюджету, які могли б бути використані на інші потреби міста, такі як ремонт доріг, будування дитячих садків тощо.

На сьогоднішній день службами зайнятості та координаційним центром Дніпропетровська надана допомога і консультація 3 приводу працевлаштування понад 6 тис. осіб. Отримують допомогу 3 безробіття майже 3 тис. осіб, а за допомогою центру зайнятості працевлаштувалися на сьогодні 1800 осіб. Однак не всі запропоновані вакантні місця $\epsilon$ актуальними для переселенців, адже найбільшим є попит на прості професії, такі як прибиральниці, столяри, електрики, ковалі, токарі, що не всіх влаштовує.

Із проблемою працевлаштування зіткнулися не лише мігранти, а й саме населення Дніпра. Рівень зареєстрованого безробіття в місті значно підвищився у зв'язку зі скороченням обсягів виробництва, падінням купівельної спроможності гривні, спричинене погіршенням зовнішньоекономічних зв'язків, підвищенням рівня інфляції та зниженням сальдо платіжного балансу. Адже зараз кожен четвертий підприємець змушений призупинити свою діяльність, оскільки або впала рентабельність, або податки виявилися непідйомними. Крім того, спостерігається загальне скорочення в діловій активності підприємництва і бюджетній сфері. Такі тенденції актуальні, на жаль, не тільки для м. Дніпро [4].

Щодо малого та середнього бізнесу, який $\epsilon$ альтернативою великій промисловості й дозволяє створювати нові робочі місця, активізувати ділову сферу, то кількість малих і середніх підприємств у розрахунку на 10 тис. осіб наявного населення у м. Дніпро становить понад 150 одиниць. Тобто у сфері підприємництва зайнято понад 220 тис. мешканців міста, їх участь у підприємницькій діяльності стає відчутнішою в наповненні місцевого бюджету. Тільки за 2014 р. до бюджету міста було перераховано рекордну суму надходжень від діяльності малого й середнього підприємництва - понад 330 млн грн, що на 37,6 $\%$ більше, ніж у 2013 р. За станом на 1 жовтня 2015 р. до бюджету міста вже надійшло 295,5 млн грн надходжень, що на 25,8 \% більше, ніж за відповідний період 2014 р. (234,8 млн грн.) [9].

Проте бізнес, пов'язаний із імпортом продукції, викликає наразі багато питань і суперечностей, враховуючи валютні коливання, які ми спостерігаємо. Як наслідок, у підприємців виникає стрімке бажання виїхати за кордон 3 метою роботи й проживання. Найчастіше українців приваблюють такі країни, як: Польща, Чехія, Словаччина, Німеччина. Найімовірніше, допоки не стабілізується політична й економічна ситуація, в Україні буде важко працювати середньому та малому бізнесу, не кажучи вже про розвиток нових напрямів або розширення бізнесу. Тільки суттєва лібералізація податкової політики може мотивувати підприємців не виводити свої активи за кордон, а й надалі працювати в Україні.

На сьогоднішній день для міграційних процесів Дніпропетровщини, та й України в цілому, характерна тенденція до інтелек- 
туалізації складу еміграції. Цю тенденцію, перш за все, спричинили фінансово-економічні проблеми останніх років, наслідком яких стала економічна криза. Адже за іiі умов значна частка висококваліфікованих фахівців не отримує можливості для належного застосування своїх знань. Саме тому зростає відсоток трудових мігрантів 3 України, зайнятих на роботах, що потребують високої кваліфікації - у медицині, науці, сфері високих технологій, фінансовому секторі [6].

Головним чинником, що стимулює трудову міграцію, є різниця в оплаті праці. За даними різних соціологічних опитувань, середньомісячний заробіток трудового мігранта коливається від 700 до 900 дол. США, якщо перевести на сьогоднішній курс, це приблизно 18000 - 20000 грн. А середня зарплата дніпропетровця, що ледь перевищує 100 євро, є майже у 20 разів меншою ніж в Італіі, у 6 разів меншою ніж у Польщі. Справа не лише в тім, що «українські мізки» та частина сильної й активної частини населення м. Дніпро переміститься до країн Європи, але й у тім, що пропрацювавши 5 - 10 років й соціально адаптувавшись там, вони не повернуться в місто на Дніпрі. Їх місце займуть вихідці з Пакистану, Афганістану, Молдови, КНР, В’єтнаму, Індії та інших менш розвинених країн, які переважно влаштовуються у сфері торгівлі, послуг тощо, тоді як українці, що виїжджають за кордон, залишають робочі місця у промисловості, будівництві, сільському господарстві [1, с. 319 - 320]. Це виражається в нових проблемах: незабезпеченість працездатними i кваліфікованими виробничими кадрами галузей української економіки (особливо науковців і фахівців), що призводить до уповільнення темпів науково-технічного прогресу; вкладання державою коштів у підготовку фахівців для потреб власної економіки, науки, які створюють додану вартість за межами країни; зростання злочинності та соціальної напруженості в суспільстві через міжнаціональні конфлікти тощо.
Висновки. Проаналізувавши сучасний стан міграційних процесів Дніпропетровщини та виявивши основні причини міграції, слід визначити основні шляхи створення більш привабливих умов для населення та запобігання міграції. Пропонуються такі кроки: розширити спектр отримання освітніх послуг, можливостей здобуття престижної професії та застосування знань і умінь на практиці (наприклад, сприяння створенню закладів професійно-технічної освіти за новими, затребуваними на ринку праці напрямами) для припливу молодого населення; підвищити привабливість області 3 огляду на перспективи пропозицій ринку праці, адекватної винагороди за роботу (у випадку найманих працівників) чи сприятливі умови для провадження власного бізнесу; створити безпечні і комфортні умови життєдіяльності; поліпшити умови проживання населення для припливу населення 3 досвідом роботи, певною кваліфікацією або 3 наміром і фінансовою спроможністю започаткувати підприємницьку діяльність.

Отже, розвиток міграцій на Дніпропетровщині зумовлений багатьма проблемами економічного, соціального та політичного характеру. Невирішення цих проблем посилює трудову міграцію, негативними наслідками якої $\epsilon$ : депопуляція населення країни; розпад сімей; відплив кращого трудового потенціалу; злочинність і корупція; політична нестабільність. Тобто необхідно забезпечити максимально ефективне використання наявного трудового потенціалу шляхом створення нових робочих місць через зростання обсягів інвестицій в основний капітал та інноваційний розвиток; удосконалити політику доходів, перш за все за рахунок підвищення рівня оплати праці, оскільки заробітна плата має відповідати рівню затрат на відтворення робочої сили; створити стимули для повернення до України мігрантів, що раніше виїхали на роботу за кордон на постійне місце проживання чи за трудовими контрактами, насамперед висококваліфікованих фахівців. 


\section{БІБЛІОГРАФІЧНІ ПОСИЛАННЯ:}

1. Борисенко О. П. Зовнішньоекономічна політика держави: концепція, стратегія, механізми реалізації: монографія. / О. П. Борисенко. - Донецьк: Юго-Восток, 2012. - 404c.

2. Головне управління Державної міграційної служби України у Дніпропетровській області. - Peжим доступу: http://dp.dmsu.gov.ua/

3. Демографічний прогноз до 2030 року для міста Дніпропетровська. Проект Розбудови спроможності до економічно обгрунтованого планування розвитку областей і міст України. - Режим доступу: http://dniprorada.gov.ua/files/dnipropetrovsk_prognoz_ukr.pdf

4. Дніпропетровський обласний центр зайнятості. Статистичні дані. - Режим доступу: http://www. dcz.gov.ua/dnp/control/uk/statdatacatalog/list

5. Допомога переселенцям у Дніпропетровську. Новий формат. Інформаційно-аналітичний портал. - Режим доступу: http://nf.dp.ua/2014/10/u-dnipropetrovsku-rozpovily-pro-poryadok-nadannyashchomisyachnoyi-adresnoyi-dopomohy-pereselentsyam/

6. Міграційна ситуація у Дніпропетровській області: стан, проблеми і шляхи їх вирішення. - Peжим доступу: http://migraciya.com.ua/news/GeneralDirectorateofLCAinDnipropetrovskregion/uamigration-situation-in-dnipropetrovsk-oblast---state-problems-and-solutions/

7. Офіційний веб-сайт Головного управління статистики у Дніпропетровській області. - Режим доступу: http://www.dneprstat.gov.ua

8. Постанова Кабінету Міністрів України від 01.10.2014 № 505 «Про надання щомісячної адресної допомоги особам, які переміщуються з тимчасово окупованої території України та районів проведення анти терористичної операції, для покриття витрат на проживання, в тому числі на оплату житлово-комунальних послуг». - Режим доступу: http://zakon3.rada.gov.ua/laws/show/505$2014-\% \mathrm{D} 0 \% \mathrm{BF}$

9. Україна в регіонах: Як Дніпропетровськ справляється з безробіттям і переселенцями. - Режим доступу: http://ua.112.ua/statji/ukraina-v-rehionakh-yak-dnipropetrovsk-spravliaietsia-z-bezrobittiam-ipereselentsiamy-217507.html

\section{REFERENCES:}

1. Borysenko O.P. (2012). Zovnishn'oekonomichna polityka derzhavy: kontseptsiya, stratehiya, mekhanizmy realizatsiyi: monohrafiya [Foreign-economic policy of the state: concept, strategy, mechanisms of implementation: monograph]. Donets'k: Yuho-Vostok.

2. Holovne upravlinnya Derzhavnoyi mihratsiynoyi sluzhby Ukrayiny u Dnipropetrovs 'kiy oblasti [Main Directorate of the State Migration Service of Ukraine in Dnipropetrovsk region]. Retrived from: http:// dp.dmsu.gov.ua/

3. Demohrafichnyy prohnoz do 2030 roku dlya mista Dnipropetrovs 'ka. Proekt Rozbudovy spromozhnosti do ekonomichno obgruntovanoho planuvannya rozvytku oblastey i mist Ukrayiny [Demographic forecast by 2030 for the city of Dnipropetrovsk. Capacity building project for economically feasible planning of development of regions and cities of Ukraine]. Retrived from: http://dniprorada.gov.ua/files/dnipropetrovsk_prognoz_ukr.pdf

4. Dnipropetrovs'kyy oblasnyy tsentr zaynyatosti. Statystychni dani [Dnipropetrovsk Oblast Employment Center. Statistics]. Retrived from: http://www.dcz.gov.ua/dnp/control/uk/statdatacatalog/list

5. Dopomoha pereselentsyam u Dnipropetrovs'ku. Novyy format. Informatsiyno-analitychnyy portal [Assistance to settlers in Dnipropetrovsk. New format. Information and analytical portal]. Retrived from: http://nf.dp.ua/2014/10/u-dnipropetrovsku-rozpovily-pro-poryadok-nadannya-shchomisyachnoyiadresnoyi-dopomohy-pereselentsyam/

6. Mihratsiyna sytuatsiya u Dnipropetrovs'kiy oblasti: stan, problemy i shlyakhy yikh vyrishennya [Migration situation in Dnipropetrovsk region: state, problems and ways of their solution]. Retrived from: http://migraciya.com.ua/news/GeneralDirectorateofLCAinDnipropetrovskregion/ua-migration-situation-in-dnipropetrovsk-oblast---state-problems-and-solutions/

7. Ofitsiynyy veb-sayt Holovnoho upravlinnya statystyky u Dnipropetrovs 'kiy oblasti [Official website of the Main Department of Statistics in Dnipropetrovsk region]. Retrived from : http://www.dneprstat.gov. ua 
8. Postanova Kabinetu Ministriv Ukrayiny vid 01.10.2014 № 505 «Pro nadannya shchomisyachnoyi adresnoyi dopomohy osobam, yaki peremishchuyut'sya z tymchasovo okupovanoyi terytoriyi Ukrayiny ta rayoniv provedennya anty terorystychnoyi operatsiyi, dlya pokryttya vytrat na prozhyvannya, $v$ tomu chysli na oplatu zhytlovo-komunal'nykh posluh" [Resolution of the Cabinet of Ministers of Ukraine dated 10/01/2014 No. 505 "On the provision of monthly targeted assistance to persons who are moving from temporarily occupied territory of Ukraine and areas of anti-terrorist operation to cover living expenses, including for payment of housing and communal services"']. Retrived from: http://zakon3.rada.gov.ua/ laws/show/505-2014-\%D0\%BF

9. Ukrayina v rehionakh: Yak Dnipropetrovs 'k spravlyayet'sya z bezrobittyam i pereselentsyamy [Ukraine in the regions: How Dnipropetrovsk cope with unemployment and displaced persons]. Retrived from: http://ua.112.ua/statji/ukraina-v-rehionakh-yak-dnipropetrovsk-spravliaietsia-z-bezrobittiam-i-pereselentsiamy-217507.html

Тарасенко Катерина Миколаӥвна - аспірантка Університету митної справи та фінансів

Адреса: 49000, м. Дніпро, вул. Володилира Вернадського 2/4

E-mail: katjuffka1992@ukr.net

Tarasenko Kateryna M. - postgraduate student

University of customs and finance

Address: 2/4, Str. Vernadsky, Dnipro, 49000, Ukraine

E-mail: katjuffka1992@ukr.net

ORCID 0000-0002-0512-0226 